Journal of Organometallic Chemistry, 336 (1987) C41-C43

Elsevier Sequoia S.A., Lausanne - Printed in The Netherlands

Preliminary communication

\title{
Trimethylsilylation of carbenoids generated in situ from allyl and benzyl halides
}

\author{
H. Andringa, Y.A. Heus-Kloos and L. Brandsma \\ Department of Metal-mediated Organic Synthesis, Padualaan 8, 3584 CH Utrecht (The Netherlands)
}

(Received September 1st, 1987)

\begin{abstract}
Efficient procedures for the trimethylsilylation of the transient carbenoids $\mathrm{H}_{2} \mathrm{C}=\mathrm{CHCH}(\mathrm{X}) \mathrm{Li}$ and $\mathrm{Ph}(\mathrm{CH}(\mathrm{X}) \mathrm{Li}(\mathrm{X}=\mathrm{Cl}$ or $\mathrm{Br})$ are described.
\end{abstract}

The pioneering investigations of Köbrich et al. [1] in the field of carbenoids have stimulated further research which has resulted in a number of useful synthetic applications [2]. The significance of the products obtained in the reactions lies in the fact that the derivatives obtained usually contain one or more halogen atoms which make them amenable to further synthetic operations.

In spite of the considerable progress in synthetic techniques and the availability of a variety of basic reagents, each with its specific properties, a number of interesting carbenoids have resisted attempts at generation and subsequent functionalization. For the generation of carbenoids from allyl and benzyl halides, bases like lithium diisopropylamide and lithium tetramethylpiperidide [3] seem the best choice, since their C-nucleophilicity (i.e. tendency to undergo allylation or benzylation) is moderate. However, these carbenoids are powerful nucleophiles, which are very likely to couple with the reactive substrates.

Addition at $--100^{\circ} \mathrm{C}$ of benzyl chloride or benzyl bromide to a solution of lithium diisopropylamide (LDA) in tetrahydrofuran (THF), followed by, quenching with trimethylchlorosilane $\left(\mathrm{Me}_{3} \mathrm{SiCl}\right)$, gave only the products $\mathrm{PhCH}_{2} \mathrm{CH}(\mathrm{X}) \mathrm{Ph}$ $(\mathrm{X}=\mathrm{Cl}$ or $\mathrm{Br}$ ) resulting from the very fast subsequent reaction of the carbenoids $\mathrm{PhCH}(\mathrm{X}) \mathrm{Li}$ with benzyl halide. Despite several approaches, including varying the rate of addition of $\mathrm{PhCH}_{2} \mathrm{X}$, using tetramethylethylenediamine in order to enhance the kinetic basicity of LDA, etc., the desired silyl derivatives $\mathrm{PhCH}(\mathrm{X}) \mathrm{SiMe}_{3}$ were formed in traces only. Excellent yields of these compounds were obtained, however, when the mixture of benzyl halide and a slight (molar) excess of $\mathrm{Me}_{3} \mathrm{SiCl}$ was added to a well-cooled solution of LDA in THF and hexane. Silylation of benzyl chloride was also accomplished with excellent yields by adding a solution of LDA in THF to a mixture, kept at $-25^{\circ} \mathrm{C}$, of benzyl chloride, a 10 to $20 \%$ molar excess of $\mathrm{Me}_{3} \mathrm{SiCl}$, 
and THF. Allyl bromide was converted into the silyl derivative $\mathrm{H}_{2} \mathrm{C}=\mathrm{CH}-\mathrm{CH}(\mathrm{Br})$ $\mathrm{SiMe}_{3}$ by a similar procedure carried out at $-60^{\circ} \mathrm{C}$. In the absence of $\mathrm{Me}_{3} \mathrm{SiCl}$ the transient carbenoid reacted with allyl bromide to form $\mathrm{H}_{2} \mathrm{C}=\mathrm{CHCH}(\mathrm{Br})$ $\mathrm{CH}_{2} \mathrm{CH}=\mathrm{CH}_{2}$.

Allyl chloride, LDA, and $\mathrm{Me}_{3} \mathrm{SiCl}$ did give the expected compound $\mathrm{H}_{2} \mathrm{C}=\mathrm{CHCH}(\mathrm{Cl}) \mathrm{SiMe}_{3}$, but owing to its high volalility no satisfactory separation from the hexane and THF could be achieved. From prenyl chloride and phenyl bromide $\left(\mathrm{CH}_{3}\right)_{2} \mathrm{C}=\mathrm{CHCH}_{2} \mathrm{X}(\mathrm{X}=\mathrm{Cl}$ or $\mathrm{Br})$, LDA, and $\mathrm{Me}_{3} \mathrm{SiCl}$, complicated mixtures were obtained which did not contain the expected products.

The successful results in our trapping experiments with $\mathrm{Me}_{3} \mathrm{SiCl}$ show that the benzyl and allyl halides react much faster with LDA than does $\mathrm{Me}_{3} \mathrm{SiCl}$, and that trimethylsilylation of the carbenoids occurs more readily than the allylation or benzylation.

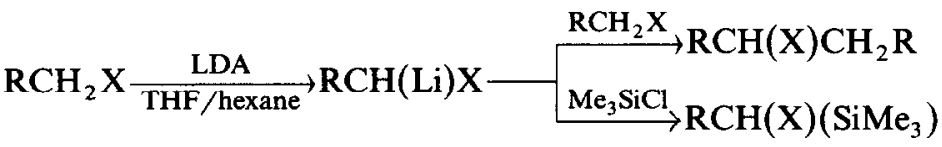

Analogous trapping experiments with allylic chlorides, LDA and alkyl bromides have been reported by McDonald [4]. Recently, Mirsadeghi and Rickborn [5] succeeded in intercepting with $\mathrm{Me}_{3} \mathrm{SiCl}$ unstable enolates generated by use of LiTMP. Mauzé, Miginiac and coworkers [6-8] generated carbenoïds derived from allylic chlorides by treating the lead compounds $\mathrm{Ph}_{3} \mathrm{PbCH}_{2} \mathrm{CH}=\mathrm{C}(\mathrm{Cl}) \mathrm{R}$ with butyllithium.

\section{Experimental}

1. Trimethylsilylation of the carbenoids from benzyl chloride and benzyl bromide. a. A mixture of $0.10 \mathrm{~mol}$ of benzyl chloride or bromide, $0.12 \mathrm{~mol}$ of $\mathrm{Me}_{3} \mathrm{SiCl}$, and 50 $\mathrm{ml}$ THF was added dropwise during $20 \mathrm{~min}$ to a solution of $0.10 \mathrm{~mol}$ of LDA in 70 $\mathrm{ml}$ of THF and $70 \mathrm{ml}$ of hexane maintained between -100 and $-110^{\circ} \mathrm{C}$. After an additional $15 \mathrm{~min}$ (at $-100^{\circ} \mathrm{C}$ ) the cooling bath was removed and the temperature allowed to rise to $-20^{\circ} \mathrm{C}$. Water $(100 \mathrm{ml})$ was added, and after separation of the layers three extractions with diethyl ether were carried out. The combined organic solutions were washed with dilute $(2 N)$ hydrochloric acid and the water. After drying over $\mathrm{MgSO}_{4}$, the solution was concentrated in vacuo, and the remaining liquid distilled through a 20-cm Vigreux column to give: $\mathrm{PhCH}\left(\mathrm{SiMe}_{3}\right) \mathrm{Cl}$, b.p. $60-65^{\circ} \mathrm{C} / 0.6 \mathrm{mmHg}, n_{\mathrm{D}}^{20} 1.5171$, in $84 \%$ yield, and $\mathrm{PhCH}\left(\mathrm{SiMe}_{3}\right) \mathrm{Br}$, b.p. $70-75^{\circ} \mathrm{C} / 0.3 \mathrm{mmHg}, n_{\mathrm{D}}^{20} 1.5386$, in $72 \%$ yield. The ${ }^{1} \mathrm{H}$ NMR spectra $(20 \% \mathrm{v} / \mathrm{v}$ solutions in $\mathrm{CCl}_{4}$, internal standard $\mathrm{CH}_{2} \mathrm{Br}_{2}, \delta 4.91 \mathrm{ppm}$ ) showed the following signals: $\mathrm{PhCH}(\mathrm{Cl}) \mathrm{SiMe}_{3}: 7.31,4.44$ and $0.31 \mathrm{ppm}$ and $\mathrm{PhCH}(\mathrm{Br}) \mathrm{SiMe}_{3}: 7.31,4.39$ and $0.31 \mathrm{ppm}$.

b. A solution of $0.10 \mathrm{~mol}$ of LDA in $50 \mathrm{ml}$ of THF and $70 \mathrm{ml}$ hexane (placed in the dropping funnel) was added dropwise during $15 \mathrm{~min}$ to a mixture of $0.12 \mathrm{~mol}$ of benzyl chloride, $0.15 \mathrm{~mol}$ of $\mathrm{Me}_{3} \mathrm{SiCl}$ and $50 \mathrm{ml}$ of THF, maintained between -25 and $-30^{\circ} \mathrm{C}$. After an additional $15 \mathrm{~min}$ water was added and the product was isolated in $91 \%$ yield as described above.

2. Trimethylsilylation of the carbenoid from allyl bromide. A solution of $0.10 \mathrm{~mol}$ of LDA in $50 \mathrm{ml}$ of THF and $70 \mathrm{ml}$ of hexane (placed in the dropping funnel) was 
added during $15 \mathrm{~min}$ to a mixture of $0.20 \mathrm{~mol}$ (excess) of allyl bromide, $0.15 \mathrm{~mol}$ (excess) of $\mathrm{Me}_{3} \mathrm{SiCl}$, and $50 \mathrm{ml}$ of $\mathrm{THF}$, maintained at $--60^{\circ} \mathrm{C}$. After an additional $15 \mathrm{~min}$ water $(100 \mathrm{ml})$ was added, followed by a mixture of $15 \mathrm{ml}$ of $36 \%$ hydrochloric acid and $200 \mathrm{ml}$ of water. After shaking and separation of the layers, four extractions with pentane were carried out. The combined organic solutions were dried over $\mathrm{MgSO}_{4}$, and most of the solvent was distilled off at atmospheric pressure through a $40 \mathrm{~cm}$ Vigreux column. Careful distillation of the remaining liquid gave $\mathrm{H}_{2} \mathrm{C}=\mathrm{CHCH}\left(\mathrm{SiMe}_{3}\right) \mathrm{Br}$, b.p. $42-44^{\circ} \mathrm{C} / 15 \mathrm{mmHg}, n_{\mathrm{D}}^{20} 1.4698$, in $75 \%$ yield. ${ }^{1} \mathrm{H}$ NMR: (20\% v/v solution in $\mathrm{CCl}_{4}, \mathrm{CH}_{2} \mathrm{Br}_{2}, \delta 4.91 \mathrm{ppm}$ as internal standard): $\mathrm{H}_{2} \mathrm{C}=\mathrm{CH}\left(\delta\right.$ 4.9-6.3 ppm, m); $\mathrm{CH}_{2}(\delta 3.67 \mathrm{ppm}, \mathrm{d})$ and $\mathrm{Me}_{3} \mathrm{Si}(\delta 0.16$ ppm, s).

Acknowledgement This work was supported by the Foundation for Technical Sciences (S.T.W.) with financial aid from the Netherlands Organization for the Advancement of Pure Research (Z.W.O.).

\section{References}

1 G. Köbrich, Angew. Chem., 84 (1972) 557.

2 H. Siegel, Topics Curr. Chem., 106 (1982) 55.

3 R.A. Olofson, C.M. Dougherty, J. Am. Chem. Soc., 95 (1973) 582.

4 T. McDonald, B. Amirthalingam Narayanan, and D.E. O’Dell, J. Org. Chem., 46 (1981) 1506.

5 S. Mirsadeghi and B. Rickborn, J. Org. Chem., 51 (1986) 986.

6 B. Mauzé, A. Doucoure and L. Miginiac, J. Organomet. Chem., 215 (1981) 1.

7 B. Mauzé, J. Organomet. Chem., 170 (1979) 265.

8 P. Ongoka, B. Mauzé and L. Miginiac, Synthesis, (1985) 1069. 